\title{
Présentation du numéro
}

\section{Introduction to this issue}

\author{
Frédéric MARQUET
}

Rédacteur en chef du numéro

Editor in chief of this issue

Adresse

de correspondance :

F. MARQUET

1 , rue de Verdun

35300 Fougères.
C'était au cours de mes études dentaires, en deuxième ou troisième année : le programme de l'après-midi comportait un cours intitulé «abord bio-psycho-social du patient». Sur le moment, je crois avoir été autant amusé qu'intrigué. Aujourd'hui, avec l'expérience, j'apprécie pleinement d'avoir pu bénéficier de cet enseignement et je considère naturel et indispensable l'intégration de ces notions au programme du deuxième cycle des études odontologiques.

Elles participent à une approche globale de notre patient, que nous nous accordons tous à considérer comme un tout indissociable. Au delà de sa dysmorphie, il nous faut essayer de prendre en compte l'ensemble de ses dimensions tant cognitive, émotionnelle que posturale.

Ainsi, la Revue d'ODF a souhaité aborder le thème de la posture, vaste sujet qui, bien qu'intéressant le plus grand nombre d'entre nous, ne bénéficie pas encore d'un large consensus. De fait, la critique et le rejet de ces notions sont plus aisés que leur présentation pédagogique et sans à priori. Pour nous aider dans cette présentation nous avons fait appel à des auteurs, tant orthodontistes que médecins ou psychologues. Celle-ci se fera sur le numéro présent ainsi que sur le suivant.

En introduction, le Pr Fenart dont nos lecteurs connaissent les travaux consacrés à la croissance cranio-faciale et à l'hominisation, nous présente la phylogenèse de la colonne vertébrale. Celle-ci a mené au squelette axial de l'Homme et elle est étroitement liée à celle des autres constituants corporels : la tête, le bassin et les membres.
One day in the second or third year of dental school I noticed that the course scheduled for that afternoon was entitled "Assessing the bio-psycho-social status of the patient." At the time I was as amused by the sound of this topic as I was intrigued by it. Today after learning from the stern teacher of experience in daily dental practice, I fully appreciate how much that course taught me and I consider that is essential for these notions to be integrated into the program of the second half of dental school studies.

They are a vital component to a modern global approach to evaluation of patients, something we all now agree upon. Beyond the physical dental defects we are called upon to treat, we must also attempt to evaluate the totality of the patient's cognitive and emotional as well as postural dimensions.

Recognizing this new aspect of dental practice, the Revue of the ODF has decided to examine the theme of posture, a vast subject that, despite its allure for a great many dentists, does not yet enjoy a large supporting consensus. In fact, it seems easier to criticize and even reject these notions than it is to prepare an effective way to teach them without some a priori basis. To help in our presentation we have relied on a variety of authors not only from the field of orthodontics but also from medicine and psychology to appear in this issue and in the one that will follow it.

In his introduction, Professor Fenart, whom our readers already know from his work devoted to growth and human development, elucidates the phylogenesis of the vertebral column. From this base an examination of the axial skeletal of Man is presented and this is shown to be inti- 
Le temps d'un article, Philippe Amat a accepté de laisser de coté les convictions qui l'ont conduit à intégrer la posture dans son exercice clinique quotidien. Il nous livre, avec la rigueur scientifique nécessaire, l'état actuel des connaissances sur les relations entre posture et occlusion, ainsi que leurs implications cliniques.

Jean-Luc Ouhioun travaille depuis longtemps avec Michel Clauzade dont il a adopté le concept d'orthoposturodontie. Il nous démontre l'intérêt d'enregistrer les bons rapports cranio-mandibulaires avant de démarrer un traitement orthodontique, ceux-ci pouvant être impliqués dans l'étiopathogénie des dysfonctions temporomandibulaires et des troubles posturaux.

La Revue d'ODF a souhaité également laisser la parole à Pierre Lecomte et Angélique Jorand. Leur étude évalue la souffrance psychologique de patients présentant un Syndrome de Déficience Posturale. Ils nous proposent un outil facilement utilisable pour nous aider à détecter les patients posturaux nécessitant une prise en charge adaptée.

Dans le numéro suivant, Pierre-Henri Dupas et al., nous préciseront leur approche des dysfonctions cranio-mandibulaires en orthopédie dento-faciale. Après une description du système tonique postural, Isabelle Gault nous fera part de son expérience posturale. Maryvonne Fournier, au cours d'un entretien qu'elle nous a accordé, nous présentera une synthèse de sa pensée et nous réexpliquera tout l'intérêt d'une bonne posture linguale de repos et d'une posture globale équilibrée.

Nous souhaitons que ce numéro et le suivant soient à la fois une source d'informations ainsi que l'occasion d'une rencontre pour vous transmettre l'élan qui nous anime. Puissent ces articles susciter un large échange d'idées interdisciplinaire, favoriser la prise en charge globale de nos patients et appeler la publication d'autres articles dans de futurs numéros.

Installez-vous confortablement, le dos bien soutenu, la tête bien droite et bonne lecture. mately related to other components of the body, the head, the pelvis, and the arms and legs.

In the space of a single article, Philippe Amat has displayed for us, with the necessary scientific rigor and objectivity, the whole range of the current state of our knowledge about the relationship between posture and occlusion and the clinical implications of this dyad even though he has already integrated assessment of and treatment of postural anomalies into his own private practice.

Jean-Luc Ouhioun has been working for some time with Michel Clauzade and has adopted his concept of orthoposturodontics. He shows us the usefulness of securing good cranio-mandibular relationships before beginning orthodontic treatment because at a later date some malfunction in that relationship could be involved in the etiopathogenesis of tempero-mandibular and postural mal-functioning.

The Revue of the ODF also wanted to publish the results of the work of Pierre Lecomte and Angélique Jorand. Their studies have evaluated the psychological distress of patients suffering from a Syndrome of Postural Deficiency. They propose a useful tool that orthodontists can employ to help them discern patients with postural problems that will need corrective assistance.

In the next issue, Pierre-Henri Dupas et al. will present a precise outline of their approach for dealing with cranio-mandibular malfunctions in dento-facial orthopedics. After describing the tonic postural system of the tongue, Isabelle Gault will share her experience in postural treatment with us. Maryvonne Fournier, in an interview we conducted with her, will give a synthesis of her thinking and again explain the importance of good rest tongue posture and of a well-balanced over-all posture.

We hope that this issue and the next one will be not only a source of information for you but also a way for us to communicate to you our enthusiasm for the subject. May these articles inspire a fruitful inter-disciplinary exchange of ideas, encourage us to take a wider view of our need to concern ourselves with the total patient, and stimulate the preparation of additional articles for future issues.

Now, get yourself seated in a comfortable chair that provides good support for your back, make sure your head is in an upright position and... enjoy your reading. 